\title{
The fish fauna of Anambra river basin, Nigeria: species abundance and morphometry
}

\author{
Gregory Ejikeme Odo ${ }^{1}$, Nwani Christopher Didigwu ${ }^{2}$ \& Joseph Effiong Eyo ${ }^{3}$ \\ 1,3. Department of Zoology, University of Nigeria, Nsukka, Nigeria; divinelovejoe@yahoo.com \\ 2. Dept of Applied Biology Ebonyi State University Abakiliki Ebonyi State, Nigeria
}

Received 03-IV-2008. C Corrected 04-VIII-2008. Accepted 02-IX-2008.

\begin{abstract}
The fish yields of most Nigeria inland waters are generally on the decline for causes that may range from inadequate management of the fisheries to degradation of the water bodies. Sustainable exploitation requires knowledge of the ichthyofaunal composition in the water bodies. We did a survey of fish species in Anambra river basin for 22 months. Fish samples were collected using four different gears -hook and line of size 13, caste nets, gill nets, and cages of mesh sizes of $50 \mathrm{~mm}, 75 \mathrm{~mm}$, and $100 \mathrm{~mm}$ each. We recorded 52 fish species belonging to 17 families: 171, 236, and 169 individuals at Ogurugu, Otuocha, and Nsugbe stations respectively. Two families, Characidae, $19.5 \%$, and Mochokidae, $11.8 \%$, constituted the dominant fish families in the river. The dominant fish species were Citherinus citherius, 9.02\%, and Alestes nurse, 7.1\%. Other fish species with significant abundance were Synodontis clarias $6.9 \%$, Macrolepidotus curvier $5.7 \%$, Labeo coubie $5.4 \%$, Distichodus rostrtus $4.9 \%$, and Schilbe mystus $4.5 \%$. The meristic features of the two most abundant fish species caught are as follows: Citharinus citharius dorsal fins 20, anal fins 30, caudal fins 21, pectoral fins, 9 and 8 ventral fins, and Alestes nurse 10 dorsal fins, 14 anal fins, 31 caudal fins, 7 pectoral fins and 6 ventral fins. The morphometric features of the two most abundant fish species are Citharinus citharius total length 300mm, standard length $231 \mathrm{~mm}$, head length $69 \mathrm{~mm}$, body length $101 \mathrm{~mm}$, body girth $176 \mathrm{~mm}$, body weight $900 \mathrm{mg}$. Alestes nurse total length 200 , standard length $140 \mathrm{~mm}$, head length $60 \mathrm{~mm}$, body length $80 \mathrm{~mm}$, body girth $120 \mathrm{~mm}$, body weight $400 \mathrm{mg}$. The most abundant animal utilizing the basin was Ardea cinerea (D3) with $22.2 \%$ occurrence (D4) and this was followed by Caprini with $13.51 \%$, and Varanus niloticus, $10.04 \%$. The least abundant animals utilizing basin were Chephalophus rufilatus, and Erythrocebus patas, with $0.58 \%$ each of occurrence. Rev. Biol. Trop. 57 (1-2): 177-186. Epub 2009 June 30.
\end{abstract}

Key words: Anambra River, ichthyofauna, biometry, Nigeria, Characidae, Mochokidae.

The fish yields of most Nigeria inland waters are generally on the decline (Jamu and Ayinla 2003). The decline of these fisheries has been attributed to a wide range of causes ranging from inadequate management of the fisheries resources to environmental degradation of the water bodies. For sustainable exploitation of these resources, a crucial management tool is to have a comprehensive understanding of the ichthyofaunal composition of the water bodies. The freshwater food fishes found in Nigeria are about 268 different fish species (Lévesque et al. 1992). They inhabit over 34 well-known freshwater bodies (rivers, lakes, and reservoirs) which constitute about $12 \%$ of Nigeria's total surface area put at 94185000 ha (Ita 1993). Fish stocks in rivers are generally replenished from their adjacent flood plains after each flood season during which fish breed. Therefore, any natural phenomenon such as drought or artificial activities such as dam construction, which eventually affect the natural cycle of flooding, will certainly undermine fish species diversity both in lakes and wetlands. Considering this fact, therefore, that lakes, wetlands and reservoirs are supplied with fish by their inflowing 
rivers, the rivers would be characterized by higher species diversity (Ita 1993). Boulenger (1916) published a list of African freshwater fishes to include 976 species, referable to 185 genera and 43 families. But Welman (1948) produced a list of 181 species of fish that could be found in Nigeria inland waters. The report also revealed that Kaduna and Sokoto-Rima Rivers have 28 and 22 species respectively, in them. Cross River, Ogun, and OsunRivers have 39,23 , and 23 fish species respectively. Ita (1993) reported that an estimated 230 species of fish have been recorded from the rivers of Nigeria but no record is available on the species present in Rivers Echi, Anambra, Oji and Adada, which all empty directly into the ocean via River Niger. Information is scanty on the biometry and relative abundance of the ichthyofauna of Anambra River. For sustainable exploitation of these fishery resources in the river basin, a crucial management tool is would be a comprehensive understanding of the ichthyofaunal composition of the water bodies. This paper provides preliminary data on the composition, biometry, and relative abundance of the ichthyofauna of Anambra River. This forms part of a large and on going study on the fishes of the river basin. The information obtained in this investigation has been used to outline desirable management measures for the species in the basin.

\section{MATERIALS AND METHODS}

The Anambra River basin: The Anambra River basin covers an area of approximately 14 $014 \mathrm{~km}^{2}$ (Awachie \& Hare 1977). The River Anambra is approximately $207.4 \mathrm{~km}$ in length, rising from the Ankpa hills (ca. 305-610m above sea level) and discharging into the River Niger at Onitsha. There are two main seasons, the dry season (October/November - March) and the rainy season (April - September/October) approximately corresponding to the dry and flood phase, respectively, of the hydrological regime. The water temperature and Secchi disc reading in the river range from $24^{\circ} \mathrm{C}$ to $31^{\circ} \mathrm{C}$ and $5 \mathrm{~cm}$ to $85 \mathrm{~cm}$, respectively (Odo 2004).
The mean annual rainfall is between $150 \mathrm{~cm}$ and $200 \mathrm{~cm}$ (Ilozumba 1980) (D5).

Between January 1998 and October 1999, monthly fish species were sampled from Ogurugu, Otuocha and Nsugbe stations of the Anambra River. The fishing gears used were of four different types, i.e. hook and line size 13, cast nets, gill nets and cages of mesh sizes of $50 \mathrm{~mm}, 75 \mathrm{~mm}$, and $100 \mathrm{~mm}$. Preservation of fish samples was in $10 \%$ formalin. The surface water temperature of the river was taken with the use of dry mercury thermometer and the $\mathrm{pH}$ was monitored using the $\mathrm{pH}$ meter on a monthly basis. The dichotomous identification method of fish species determination arranged by Boulenger (1916) and Welman, (1948) and adopted by Oguzie (1997), was used to identify fish species. This was achieved by taking account of the meristic features of the various fishes. These features were dorsal, anal, caudal, pectoral, and ventral fin rays and spines, where present measurements were also taken on sampled fishes to aid the identification process. The morphometric data of each individual were taken. These measurements include total length of the fish (TL), measured from the mid-tip of the snout to the lateral mid base of the caudal fin, head-length (HL), which was measured from the mid-tip of the snout to the postero-dorsal junction of the membranous margin of the gill opening with the body, body depth (BD) and body girth (BG) (D6). The total number of fish caught from the river was recorded; this enabled the determination of the relative abundance of the various species in the river. The main system of classification of the species that were caught in the river was that of Madison (1992) (D8) as adopted by Babatunde and Raji, (1998). Aquatic and domestic wildlife animals sighted during the periods of data collection were counted and recorded. Droppings of domesticated animals utilizing the flood plain were evaluated and identified.

Data Analysis: The faunal similarities at different locations, based on nominal data, were analyzed using the Jackson Index (1989). The relative abundance of taxa that were 
common among the stations was calculated using Renkonen similarity (Renkonen 1975), and the Bellinger coefficient (Bellinger 1974) was calculated to evaluate discontinuities in the longitudinal distribution of species richness (d). The Shannon-Weiner index $(\mathrm{H})$ and evenness index (Shannon and Wiener 1963) (E) were used to evaluate species diversity; Hutcheson's t-test was performed to detect the significant difference between general diversity indices. The mean Fulton's condition (K) of ten common and abundant species among the three stations was calculated (Bagenal \& Tesch 1978) and compared using unpaired t-test $\left(\mathrm{n}_{1} \# \mathrm{n}_{2}\right)$; percentage data were transformed before analysis (Zar 1984). The total and relative abundance of aquatic and other animals utilizing the basin were calculated.

\section{RESULTS}

The results of the study showed that 52 fish species belonging to 17 families were recorded which comprised 171, 236, and 169 individual specimens at Ogurugu, Otuocha, and Nsugbe stations respectively (Table 1). Two families, Characidae 19.97\%, and Mochokidae 11.8\%, constituted the dominant fish families in the river (D7). Citharinus citharius $9.02 \%$, and Alestes nurse $7.3 \%$ ( D8), were the dominant species respectively. Other fish species with significant abundance were Synodontis clarias $6.9 \%$, Macrolepidotus cuvier 5.7\%, Labeo coubie $5.4 \%$, Distichodus rostartus $4.9 \%$, and Schilbe mystus $4.5 \%$. The meristic features of the two most abundant fish species caught were as follows: Citherinus citharius had: Dorsal fins, 20, Anal fins, 30, caudal fins 21, pectoral fins 9 and 8 ventral fins. Alestes nurse had 10 dorsal fins, 14 anal fins, 31 caudal fins, 7 pectoral fins and 6 ventral fins Table 3 (D9). The morphometric features of the two most abundant fish species are Citherinus citharius: total length $300 \mathrm{~mm}$, standard length $231 \mathrm{~mm}$, head length $69 \mathrm{~mm}$, body length $101 \mathrm{~mm}$, body girth $176 \mathrm{~mm}$, body weight $900 \mathrm{mg}$. Alestes nurse: Total length $200 \mathrm{~mm}$, standard length $140 \mathrm{~mm}$, head length $60 \mathrm{~mm}$, body length $80 \mathrm{~mm}$, body girth $120 \mathrm{~mm}$, body weight $400 \mathrm{mg}$ (Table 3). All the most abundant and common fish species among the three stations were in good condition $(\mathrm{K}>1)$ (Table 6). Members of Ardeidae aquatic animal family were the most abundant and they were followed by Acciptridae while Sirenia were the least occurring in the basin (Table 7) (D10). The most abundant animal utilizing the basin was the Ardea cinerea (D11), with $22.2 \%$ occurrence and this was followed by Caprini sp. with 13.51\%, and Varanus niloticus (D12) with $10.04 \%$. The least abundant animals utilizing the basin were Chephalophus rufilatus and Erythrocebus patas with $0.58 \%$ of occurrence each (Table 7).

\section{DISCUSSION}

The catch composition from this study showed that Characidae, $19.5 \%$, and Mochokidae, $11.8 \%$, constituted the dominant fish families in the river. Regarding catch and species composition, our results agreed with other studies conducted on a number of rivers in Nigeria. Analysis of catch in the preliminary survey of the fresh water fish of Nigeria by Welman, 1948, revealed that Kaduna and Sokoto/Rima rivers have Mochokidae, 28, and Osteoglossidae, 22, species respectively in them. In Cross River, Ogun and Osun rivers, 39, 23, and 27 fish species were recorded from them. But in this study, 52 fish species were recorded from the river, which comprised 171236 and 169 individual fish specimens at Ogurugu, Otuocha and Nsugbe respectively .The trend in the development of fish fauna and the sequence of changes in fish populations are complex and variable in south-eastern African rivers. The present fauna in the river is dominated by weed associated mesopredators (Welcomme, 1979). Our results suggest low inter-annual variation in species composition. These may be based on stable phytoplankton populations, nutrient and physicochemical parameters (not studied). Perhaps in-situ manipulations of isolated portions of this system would be needed to demonstrate such interrelations. It is possible that the very low number of fish species recorded at 
TABLE 1

Percentage composition of fish caught from Anambra River Basin

Fish species

\section{Clupeid}

Pellonula afzelinusGünter 1968

Gynothrisamento regan

Sierathrissa leonensis Boulenger 1908

Papyrocranus afer

Xenomystus nigri Gunther 1868

Pantodon bucholzi Peters 1902

\section{Osteoglossidae}

Heterotis niloticus Muller 1843

Gymnarchus niloticus Cuvier 1829

\section{Mormyridae}

Mormyrus fume Leach 1818

Petrocephalus bane Boulenger 1898

Petrocephalus simus Boulenger 1898

\section{Characidae}

Hydrocynus lineatus Bleeker 1861

Hydrocynus brevis Gunther 1864

Hydrocynus forskhali Cuvier 1819

Hepsetus Odoe Black 1794

Alestes nurse Ruppłe1832

Macrolepidotus (Alestes) Cuvier 1849

Alestes deutex Linnaeus 1757

Alestes baremosa

Micralestes acutidens Petae 1868

\section{Citharinidae}

Citharinus citharus Geoffrey 1809

\section{Cyprinidae}

Labeo senegalensis Cuvier 1840

Labeo coubie Rupple 1832

\section{Distichontidae}

Distichodus rostratus Muller 1864

\section{Ichthyobridae}

Phago loricatus Gunther 1865

\section{Bagridae}

Bagrus bayad macopterus (Boulenger) 1875

Chysichthys nigrodigitatus Lacepede 1802

Chrysichthys auratus Geoffroy 1809

Clarotes laticeps Rupple, 1829
Number (percentage) of fish caught Ogurugu Otuocha

$9(1.5)$

4(0.9)

$1(0.2)$

$4(0.7)$

$17(2.9)$

2(0.3)

$1(0.2)$

2(0.3)

1(0.2)

8(1.4)

1(0.2)

1(0.2)

10(1.7)

7(1.2)

1(0.2)

$3(0.5)$

4(0.7)

$1(0.2$

1(0.2)

1(0.2)

27(4.6)

2(0.3)

3(0.5)

1(0.2)

$5(0.8)$

1(0.2)

-

1(0.2)

2(0.3)

1(0.2)

$3(0.5)$

2(0.3)

-

2(0.3)

$1(0.2)$

2(0.3)

1(0.2)

3(0.5)

16(2.7)

$12(2.0)$

16(2.7)

1(0.2)

$4(0.7)$

42(7.1)

1(0.2)

10(1.7)

10(1.7)

33(5.6)

4(0.7)

8(1.4)

11(1.9)

15(2.6)

6(1.0)

$6(1.0)$

11(1.9)

1(0.2)

1(0.2)

1(0.2)

2(0.3)

14(2.4)

36(6.3)

$52(9.0)$

3(0.5)

11(1.9)

2(0.3)

16(2.8)

15(2.5)

$8(1.4)$

$8(1.4)$

31(5.4)

13(2.2)

6(1.0)

9(1.5)

28(4.9)

1(0.2)

2(0.3)

1(0.2)

4(0.7)

2(0.3)

1(0.2)

2(0.3)

$5(0.8)$

$1(0.2)$

$7(1.2)$

5(0.8)

13(2.3)

1(0.2)

3(0.5)

4(0.7)

4(0.7)

7(1.2)

$16(2.8)$ 
TABLE 1 (Continued)

Percentage composition of fish caught from Anambra River Basin

\begin{tabular}{|c|c|c|c|c|}
\hline \multirow{2}{*}{ Fish species } & \multicolumn{3}{|c|}{ Number (percentage) of fish caught } & \multirow{2}{*}{ total No $(\%)$} \\
\hline & Ogurugu & Otuocha & Nsugbe & \\
\hline \multicolumn{5}{|l|}{ Auchenoglanis biscutatus } \\
\hline Cuvier and Valencinnes 1840 & - & $2(0.3)$ & - & $2(0.4)$ \\
\hline \multicolumn{5}{|l|}{ Clariidae } \\
\hline Clarias anguillaris Linnaeus 1762 & $5(0.8)$ & $11(1.9)$ & $5(0.8)$ & $21(3.5)$ \\
\hline Clarias lazera Cuvier and Valencinnes 1840 & $3(0.5)$ & $11(1.9)$ & $2(0.3)$ & $16(2.7)$ \\
\hline Heterobranchus bidorsalis Geoffroy, 1818 & - & $7(1.2)$ & - & $7(1.2)$ \\
\hline \multicolumn{5}{|l|}{ Malapteruridae } \\
\hline Malapterurus electricus Forskali 1775 & - & $4(0.7)$ & $3(0.5)$ & $7(1.2)$ \\
\hline \multicolumn{5}{|l|}{ Mochokidae } \\
\hline Synodontis ocellifer & $2(0.3)$ & $4(0.7)$ & - & $6(1.0)$ \\
\hline Synodontis gambiensis Cuvier 1840 & $1(0.2)$ & $4(0.7)$ & $1(0.2)$ & $6(1.04)$ \\
\hline Synodontis nigrita Cuvier 1840- & $1(0.2)$ & $4(0.7)$ & $1(0.2)$ & $6(1.04)$ \\
\hline Synodontis clarias Linnaeus 1762 & $8(1.4)$ & $16(2.7)$ & $6(2.7)$ & $40(6.9)$ \\
\hline S. gobroni & - & $2(0.3)$ & - & $2(0.4)$ \\
\hline S. membranaceus Geoffroy, 1809 & $1(0.2)$ & $(0.2)$ & $1(0.2)$ & $3(0.5)$ \\
\hline S. batensoda Ruppel 1832 & $4(0.7)$ & $1(0.2)$ & - & $5(0.9)$ \\
\hline \multicolumn{5}{|l|}{ Schilbeidae } \\
\hline Physailia pellucida Boulenger, 1901 & - & $4(0.7)$ & - & $4(0.7)$ \\
\hline Schilbe mystus Linnaeus 1762 & $6(1.0)$ & $12(0.3)$ & $8(1.4)$ & $26(4.5)$ \\
\hline Siluranodon auritus Bleeker 1858 & - & - & $1(0.2)$ & $1((0.2)$ \\
\hline \multicolumn{5}{|l|}{ Channidae } \\
\hline Ophyocephalus scurus Guntheri 1861 & $1(0.2)$ & $1(0.2)$ & $1(0.2)$ & $3(0.5)$ \\
\hline \multicolumn{5}{|l|}{ Pomadasydae } \\
\hline Pristopoma jubeleni Cuvier & - & $1(0.2)$ & - & $1(0.2)$ \\
\hline Ctenopoma kings leyae Cuvier 1864 & - & $1(0.2)$ & - & $1(0.2)$ \\
\hline \multicolumn{5}{|l|}{ Centropomidae } \\
\hline Lates niloticus Linnaeus 1762 & $3(0.5)$ & $2(0.3)$ & $3(0.5)$ & $8(1.4)$ \\
\hline \multicolumn{5}{|l|}{ Cichlidae } \\
\hline Tilapia zillii Gervais 1848 & $9(1.5)$ & $4(0.7)$ & $5(0.8)$ & $18(3.1)$ \\
\hline T. nilotica Linnaeus 1757- & $2(0.3)$ & - & - & $2(0.3)$ \\
\hline T. galilaea Artedi 1757 & $3(0.3)$ & $3(0.3)$ & $4(0.7)$ & $10(1.3)$ \\
\hline \multicolumn{5}{|l|}{ Tetraonontidae } \\
\hline Tetraodon fahake Steindachner 1870 & $10(1.7)$ & - & - & $10(1.7)$ \\
\hline Total & 171 & 236 & 169 & 576(D14) \\
\hline
\end{tabular}

\section{Total}


TABLE 2

Preliminary check-list of aquatic and other animals utilizing Anambra flood plain

\begin{tabular}{|c|c|}
\hline Common name & Species \\
\hline Plover & Charadridae \\
\hline Wated plover & Venellus senegallus \\
\hline Little ringed plover & Charadrius dubius \\
\hline Egret & Ardeidae \\
\hline \multirow[t]{2}{*}{ Ardea Cattle egret } & Ardeola ibis \\
\hline & Egretta garzetta \\
\hline Little egret heron & Ardea cinerea \\
\hline Duck/geese & Antidae \\
\hline \multirow[t]{2}{*}{ Pygmy goose } & Nettapus auritus \\
\hline & Jananidae \\
\hline Little trotler & Actophilornils Africana \\
\hline \multirow[t]{2}{*}{ White-headed vulture } & Acciptridae \\
\hline & Trigonoceps occipitallis \\
\hline Kite & Milvus migrans \\
\hline Short-toed eagle & Ciraeceatus gallicus \\
\hline \multirow[t]{2}{*}{ Fish eagle } & Haliaetus vocites \\
\hline & Artiodactyla \\
\hline Bushbuck & Tragelaphus scriprus \\
\hline Buffalo-bush-cow & Syncerns caffer \\
\hline Red-flanked duiker & Chephalophus rufilatus \\
\hline \multirow[t]{2}{*}{ Kob } & Kobus kobus \\
\hline & Lagomorphs \\
\hline \multirow[t]{2}{*}{ Hare } & Lepus capensis \\
\hline & Primate \\
\hline \multirow[t]{2}{*}{ Red patas monkey } & Erythrocebus patas \\
\hline & Sirenia \\
\hline \multirow[t]{2}{*}{ African manatee } & Trichechus senegalensis \\
\hline & Reptilia \\
\hline \multirow[t]{2}{*}{ Monitor lizard } & Varanus niloticus \\
\hline & Chelidae \\
\hline Artiodactyla & Tortoise \\
\hline \multirow[t]{2}{*}{ Cattle } & Bovidae \\
\hline & Bos taurus \\
\hline \multirow[t]{2}{*}{ Goats \& Sheep } & Capriniae \\
\hline & Caprini sp. \\
\hline
\end{tabular}


TABLE 3

Meristic features of fish species caught in Anambra River, Nigeria

\begin{tabular}{|c|c|c|c|c|c|c|}
\hline & $\mathrm{N}$ & D. fin & A. fin & C. fin & P. fin & V. fin \\
\hline Papyrocranus afer & 27 & 6 & 70 & 6 & 9 & - \\
\hline Alestes nurse & 42 & 10 & 14 & 31 & 7 & 6 \\
\hline Macrolepidotus Cuvier & 33 & 9 & 20 & 21 & 6 & 5 \\
\hline Citharinus citharius & 52 & 20 & 30 & 21 & 9 & 8 \\
\hline Labeo coubie & 31 & 12 & 10 & 17 & 8 & 6 \\
\hline Distichodus rostatus & 28 & 26 & 12 & 20 & 4 & 5 \\
\hline Clarias anguillaris & 21 & 70 & 59 & 11 & 4 & 3 \\
\hline Synodontis clarias & 40 & 7 & 8 & 18 & 9 & 4 \\
\hline Schilbe mystus & 26 & 6 & 62 & 19 & 8 & 4 \\
\hline Tilapia zilli & 18 & 15 & 10 & 13 & 11 & 7 \\
\hline
\end{tabular}

Numerals represent number of fin rays: D. Fin: Dorsal fin; A. Fin: Anal Fin; C. Fin: Caudal Fin; P. Fin: Pectoral Fin; V. Fin: Ventral Fin.

TABLE 4

Morph metric features of fish species caught in Anambra River, Nigeria

\begin{tabular}{|c|c|c|c|c|c|c|c|}
\hline Papyrocranus afer & 27 & 571 & 395 & 80 & 90 & 160 & 301 \\
\hline Alestes nurse & 42 & 200 & 140 & 60 & 80 & 120 & 400 \\
\hline Macrolepidotus cuvier & 33 & 481 & 401 & 90 & 130 & 180 & 700 \\
\hline Citharinus citharius & 52 & 300 & 231 & 69 & 101 & 176 & 900 \\
\hline Labeo coubie & 31 & 600 & 501 & 122 & 140 & 191 & 1001 \\
\hline Distichodus rostatus & 28 & 480 & 411 & 96 & 110 & 171 & 1200 \\
\hline Clarias anguillaris & 21 & 800 & 602 & 180 & 171 & 196 & 1160 \\
\hline Synodontis clarias & 40 & 240 & 203 & 109 & 190 & 170 & 270 \\
\hline Schilbe mystus & 26 & 280 & 210 & 80 & 140 & 130 & 240 \\
\hline Tilapia zillii & 18 & 275 & 201 & 79 & 97 & 200 & 230 \\
\hline
\end{tabular}

All measurements are millimeters (mm): TL: Total Length; SL: Standard Length; HL: Head Length; BD: Body Length; BG: Body Girth; BW: Body weight (mg).

TABLE 5

Diversity of fish fauna in the Anambra River

\begin{tabular}{lccc}
\multicolumn{1}{c}{ Sampled station } & Ogurugu & Otuocha & Nsugbe \\
Number of samples & 44 & 44 & 44 \\
Number of species & 51 & 52 & 51 \\
Number of individuals & 171 & 236 & 169 \\
Species richness (d) & 3.19 & 3.01 & 2.97 \\
General diversity (H) & 0.82 & 1.10 & 0.78 \\
Evenness (E) & 0.56 & 0.70 & 0.49
\end{tabular}


TABLE 6

Comparison of mean Fulton's condition factors $\left(k^{1}\right)$ for common and abundant fish species, Anambra River

\begin{tabular}{|c|c|c|c|c|c|c|c|}
\hline \multirow{2}{*}{ Fish species } & \multicolumn{2}{|c|}{ Ogurugu } & \multicolumn{2}{|c|}{ Otuocha } & \multicolumn{2}{|c|}{ Nsugbe } & \multirow{2}{*}{$\mathrm{t}$-value } \\
\hline & $\mathrm{N}$ & Mean \pm tsd & $\mathrm{N}$ & Mean \pm tsd & $\mathrm{N}$ & Mean \pm tsd & \\
\hline Papyrocranus afer & 17 & $2.04 \pm 0.49$ & 4 & $1.47 \pm 0.10$ & 6 & $2.89 \pm 0.31$ & 1.81 \\
\hline Alestes nurse & 16 & $1.20 \pm 0.30$ & 16 & $2.71 \pm 0.35$ & 10 & $2.09 \pm 0.31$ & 0.49 \\
\hline Macrolepidotus cuver & 12 & $2.50 \pm 0.33$ & 10 & $2.50 \pm 0.33$ & 11 & $2.71 \pm 0.5$ & 0.45 \\
\hline Citharinus cithanus & 12 & $3.02 \pm 0.41$ & 14 & $3.62 \pm 0.51$ & 36 & $3.19 \pm 0.62$ & 0.53 \\
\hline Labeo coubie & 15 & $1.17 \pm 0.45$ & 8 & $1.91 \pm 0.23$ & 8 & $1.91 \pm 0.23$ & 0.20 \\
\hline Distichodus rostratus & 23 & $3.01 \pm 0.10$ & 6 & $2.01 \pm 0.50$ & 9 & $2.01 \pm 0.50$ & 0.37 \\
\hline Clarias anguillaris & 5 & $1.51 \pm 0.20$ & 11 & $1.78 \pm .32$ & 5 & $1.78 \pm .32$ & 0.67 \\
\hline Synodontis clarias & 17 & $2.3 \pm 0.31$ & 16 & $2.08 \pm 0.10$ & 16 & $2.08 \pm 0.10$ & 0.20 \\
\hline Schilbe mystus & 6 & $1.89 \pm 0.32$ & 12 & $1.87 \pm 0.30$ & 8 & $1.87 \pm 0.30$ & 0.57 \\
\hline Tilapia zillii & 9 & $2.60 \pm 0.41$ & 4 & $1.80 \pm 0.21$ & 5 & $1.80 \pm .21$ & 0.67 \\
\hline
\end{tabular}

TABLE 7

The relative abundance of aquatic and other animals utilizing Anambra river basin

\begin{tabular}{|c|c|c|c|c|}
\hline \multirow{2}{*}{ Species } & \multicolumn{3}{|c|}{ Number (percentage) of animals caught per station } & \multirow{2}{*}{ Total No $(\%)$} \\
\hline & Ogurugu & Otuocha & Nsugbe & \\
\hline Venellus senegallus & $2(0.39)$ & $6(1.16)$ & $1(0.39)$ & $9(2.32)$ \\
\hline Charadrius dubius & 0 & $2(0.39)$ & $3(0.58)$ & $5(0.96)$ \\
\hline Ardeola ibis & $1(0.19)$ & 0 & $5(0.96)$ & $6(1.16)$ \\
\hline Egretta garzetta & $20(3.4)$ & $10(1.9)$ & $8(3.47)$ & $48(9.27)$ \\
\hline Ardea cinerea & $30(5.8)$ & $35(6.76)$ & $50(965)$ & $115(22.20)$ \\
\hline Nettapus auritus & 0 & $3(0.58)$ & $1(0.19)$ & $4(0.77)$ \\
\hline Actophilornils africana & $5(0.96)$ & $10(1.9)$ & $2(0.39)$ & $17(3.28)$ \\
\hline Trigonoceps occipitallis & $10(1.9)$ & $17(3.28)$ & $4(0.77)$ & $31(5.98)$ \\
\hline Milvus migrans & $12(2.3)$ & $9(1.74)$ & $3(0.58)$ & $24(4.63)$ \\
\hline Ciraeceatus gallicus & 0 & $6(1.16)$ & $2(0.4)$ & $8(1.54)$ \\
\hline Haliaetus vocites & $1(0.19)$ & 0 & $4(0.77)$ & $5(0.96)$ \\
\hline Tragelaphus scriprus & $2(0.39)$ & 0 & $6(1.16)$ & $8(1.5)$ \\
\hline Syncerns caffer & $1(0.19)$ & 0 & $2(0.39)$ & $3(0.58)$ \\
\hline Chephalophus rufilatus & 0 & $3(0.58)$ & 0 & $3(0.58)$ \\
\hline Kobus kobus & $2(0.39)$ & $2(0.39)$ & 0 & $4(1.16)$ \\
\hline Lepus capensis & $4(0.77)$ & $7(1.40)$ & $11(2.12)$ & $22(4.25)$ \\
\hline Erythrocebus patas & $2(0.39)$ & 0 & $1(0.19)$ & $3(0.58)$ \\
\hline Trichechus senegalensis & $11(2.120)$ & $8(1.5)$ & $1(0.19)$ & $20(3.86)$ \\
\hline Varanus niloticus & $20(3.86)$ & $19(3.67)$ & $13(2.51)$ & $52(10.04)$ \\
\hline Bos indicus & $5(0.96)$ & $20(2.12)$ & $15(2.90)$ & $40(7.72)$ \\
\hline Caprini & $26(5.01)$ & $31(5.98)$ & $13(5.98)$ & $70(13.51)$ \\
\hline Tortoise sp. & $1(0.19)$ & $4(0.77)$ & 0 & $5(0.96)$ \\
\hline Total & 155 & 192 & 169 & 516 \\
\hline
\end{tabular}


Ogurugu and Nsugbe stations must have been as a result of synergistic effects from the various industries. These effects were discharge of municipal wastes and individual pollutants including warm- water effects from power stations. Toxic effects of detergents, petroleum products and household factories have been documented (Omoregie, 1995). In addition to the fish species found in the river, there are some other forms of aquatic fauna. The crab Sudanonantes african occurs in large quantity, as well as snails, crocodiles, and snakes. Both the numbers and distribution of large mammals on the River basin have been greatly reduced due increased human influence such as hunting, burning, (Ndakide 1988, personal communication). Fish eating birds, always the most abundant species, were confined largely to the vicinity of River Anambra and shoreline. Domestic animal populations are on the increase. The moist and easily saturated soil condition for some months of the year might favour growth of herbaceous grasses and forbs which could serve as fodder to the livestock. In fact more than 300 domestic animals were counted during the dry season utilizing the plain. The availability of forage species coupled with perennial fodder shortage for the Nigeria livestock populations indicate that River basin might serve a good dry season grazing areas for both resident animals. This confirms that natural aquatic environment houses a variety of aquatic lives (Kindersley,1991). The surface temperature undergoes relatively small fluctuations, there was a fairly consistent thermal regime of about $29.5^{\circ} \mathrm{C}$ and the $\mathrm{pH}$ range was between 6.8 and 7.7. This range fell within the recommended range that support aquatic life including fishes (Boyd,1979). The water quality of the river can be improved further by controlling and /or prohibiting the discharge of municipal effluents and domestic garbage into the river as well as the use of the riparian zone for crop agriculture. The maintenance of a 50-60 $\mathrm{m}$ thick riparian vegetation can act as a buffer strip to check erosion by acting as sediment break/filter.

\section{REFERENCES}

Awachie, J.B.E. \& Hare, L. 1977. The fisheries of the Anambra, Ogun and Oshun river systems in Southern Nigeria. CIFA Technical paper 5, p. 170-184.

Abatunde, D.O.\& Raji, A. 1998. Field Guide to Nigeria Freshwater Fisheries Technology, New Bussa. p. 1-2, 84-92.

Bagenal, T.B. \& Tesch, F.W. 1978. Age and growth. p. 101-136. In T.B. Bagenal (ed.). Methods for the assessment of fish production in freshwater. IBP Handbook No. 3. Blackwell Scientific Publications, Oxford.

Bellinger, R. 1974. The measurement of species Habitat distribution and abundance. Ann. Rev. Ecol System. 5: 285-307.

Boulenger, G.A. 1916. Catalogue of the Freshwater Fishes of Africa in the British Museum (Natural History). Vol.IV, Trustees, London, 392 p.

Boyd, C.E. 1979. Water Quality in Warm Water Fish ponds. Agricultural Station, Auburn University, Alabama. $35 \mathrm{p}$.

Ilozumba, P.C.O. 1989. Studies on the ecology and biology of Tennisentis niloticus (Meyer 1992) Van Cleane, 1936 Acanthocephala. Ph.D. Thesis. University of Nigeria, Nsukka, Nigeria. 204 p.

Ita, E.O. 1993. Inland Fishery Resources of Nigeria.FAO, CIFA Occasional Paper No. 20, Rome, Italy, FAO. $120 \mathrm{p}$.

Jackson, L. 1989. Similarity coefficient, measures of cooccurrence and association or simply measures of occurrence. American Naturalist 133: 436-453.

Jamu, D.M. \& Ayinla,A.O. 2003. Potential for the Development of Agriculture in Africa. NAGA, 26(3): 9-13.

Kindersley. 1991. The Visual Dictionary of Animals. Eye witness visual Dictionaries Book. First American Edition. p. 20-59.

Lévesque, C., Paugy, D. \& Teugel, C.U. 1992. Fauna ies paisons d'eaoax douse et Samatres de L.A trique de our et, Tome I. ORSTOM/MRAC, Paris, 384 p. 
Maddison, R.E. 1992. The Complete Aquarium Enclopedia of Tropical Freshwater Fish. p116-216.

Odo, G.E. (2004). Studies on the ecology of macro invertebrate fauna as fish food in Anambra river basin, Nigeria. Ph.D. Thesis. University of Nigeria, Nsukka, Nigeria. $192 \mathrm{p}$.

Oguzie, F.A. 1997. A KEY TO SOME OF FRESHWATER FISHES OF Nigeria (Adopted from Boulenger and Welman).Dept of Fisheries, University of Benin, Benin City. p. 1-14.

Omoregie, E. 1995. Acute toxicity of alkybenzen sulphonate (ABS) detergent to the tooth carp Aphysoemion Gardneri. Aquaculture Research 26: 755-758.
Renkonen, R. 1975. Patterns of species relative abundance and diversity, pp. 81-126. In L. Cody and J. Diamond (eds.). Ecology and Evolution of communities. Harvard University press (Belknap press), Cambridge, EEUU.

Shannon, C.E. and Wiener, W. 1963. The Mathematical Theory of communication. U. Illinois, Urbana, Illinois. $117 \mathrm{p}$.

Welcome, R.L. 1979. Fisheries ecology of Flood Plain Rivers. Longman G, London.

Welman, J.B. 1948. Preliminary survey of the Freshwater Fisheries of Nigeria. Government, Lagos, Nigeria.

Zar. J.H. 1984. Biostatistical analysis. Prentice Hall, New Jersey, USA. 